\title{
Polymorphism and Damage of Aphids (Homoptera: Aphidoidea)
}

\author{
Alla Vereschagina $^{1} \&$ Elena Gandrabur ${ }^{1}$ \\ ${ }^{1}$ Russian Academy of Sciences, All Russian Institute for Plant Protection (VIZR), Saint-Petersburg, Pushkin, Russia \\ Correspondence: Elena Gandrabur, All Russian Institute for Plant Protection, Podbelski road, 3, Saint-Petersburg, \\ Puskin 196608, Russia. Tel: 7-812-470-4384. E-mail: helenagandrabur@gmail.com
}

Received: April 10, $2014 \quad$ Accepted: April 27, $2014 \quad$ Online Published: September 20, 2014
doi:10.5539/ijb.v6n4p124
URL: http://dx.doi.org/10.5539/ijb.v6n4p124

\begin{abstract}
The paper presents an analysis of original and published data on the ways of interaction of aphids with their host plants, the abiotic environment, other aphids and various other organisms, in relation to the specific traits of their biology, epigenesis, and migrations. Special attention is paid to the factors determining the colonial mode of life and the factors controlling the formation of alate morphs during the vegetation period. It is shown that damage of aphids is determined by their mode of feeding on plant sap, gregariousness, short- and long-range dispersal, and intraspecific variation. The factors controlling polymorphism in aphids are classified for the first time and a diagram showing their action is proposed. The importance of alate morph development in aphids as a factor and an indicator of their damage is demonstrated.
\end{abstract}

Keywords: aphids, polymorphism, crowding, migrations, life cycle, damage

\section{Introduction}

Aphids are a large group of insects (Insecta: Homoptera) including about 4700 species, of which about 1000 occur in Europe. Despite the general diversity of the biocenotic roles of aphids, the attention of experts is mainly focused on the "cereal" aphid species since they can cause considerable yield loss due to their abundance, the specific mode of feeding on plant sap, ecological polymorphism, and the ability to transmit viral diseases of plants even at very low abundance. The alate aphids not only disperse viruses but also provide links between the aphid populations of various regions. The resulting interpopulation gene exchange creates the basis for selection of aphid clones with different life cycles, host preferences, and other properties. Among the ways of aphid control the first place is still held by the chemical method, but this method should be avoided due to environment pollution and the resulting health risks. Increasingly greater attention is paid to more environment-friendly means of plant protection, such as biological and agrotechnical methods, selection of resistant cultivars, development of transgenic genotypes, etc. The existing methods of short-term and long-term prediction of the aphid population dynamics are not always efficient. Due to their intrapopulation variability, aphids quite rapidly get adapted to insecticides, resistant cultivars, and climatic factors. The use of entomophages is hindered by the sheltered life of many aphid species among leaves or in galls and by their escape behavior (dropping off the plant), whereas the immune system of aphids is sometimes capable of protecting them from parasites. Aphids may possess some other defense mechanisms as well. The outbreaks of aphids may be unpredictable because of the gaps in the knowledge of their biology and interactions with the host plant. These gaps may be partly filled by considering some key aspects of the colonial mode of life and formation of alate morphs responsible for dispersal and host plant selection in the different periods of the aphid life cycle. Studies carried out on aphids as model objects may also help to understand the general biological effects of crowding on animal development and the mechanisms of biological invasions.

This communication presents a brief review of the original material and data published by various authors on the problem of aphid polymorphism, which appeared in the course of historical development of their life cycles and is controlled by the gregarious mode of life, interactions with other taxa, and climatic and anthropogenic factors, in relation to the kinds of damage inflicted to plants. Special attention is devoted to the gregarious mode of life and formation of alate morphs during the aphid life cycle. 


\section{The Life Cycles and Morphs of Aphids}

The damage to cultivars caused by aphids is always determined by the specific traits of their trophic relations with the host plant (including the way of feeding on the plant sap) and their life cycles. Only the representatives of the families Adelgidae and Phylloxeridae feed on the plant parenchyma while all the remaining species of aphids consume phloem sap (Vereschagin et al., 1985). The established life cycles of aphids reflect their trophic relations. Development of holocyclic aphids usually includes alternation of one sexual and 10-20 parthenogenetic generations and is accompanied by polymorphism, whereas in heteroecious species it also involves transition from the primary (winter, arboreal) host plant to the secondary (summer, herbaceous) one. Host alternation is known in only $10 \%$ of aphid species, whereas the majority is autoecious and monophagous. However, most of the aphids damaging cultural plants are either heteroecious species or autoecious but polyphagous ones (Dixon, 1977).

The sexual generation may be "lost" in the aphid populations developing under constant climatic conditions, for example, in the southern parts of their ranges or in greenhouses; this results in a reduced, or anholocyclic, development cycle. Some aphid species, in particular Eriosoma lanigerum, Rhopalosiphum maidis, and Aphis gossypii, have lost the sexual generation due to disappearance of their primary host plants. During the vegetative period the aphid population includes several adult morphs somewhat differing in morphology, behavior, and demographic parameters (Shaposhnikov, 1986; Powel \& Hardie, 2001; Vereschagina, 2008; Webster, 2012). The complete life cycle of aphids usually includes the following morphs: parthenogenetic fundatrices and alate emigrants in spring, alate and apterous viviparous females (viviparae) in summer, and alate remigrants (sexuparae, gynoparae, androparae) as well as males and oviparous sexual females in autumn. The emigrants fly from the primary hosts to the secondary ones at the beginning of summer, whereas the remigrants return from the secondary hosts to the primary ones in autumn. On the primary host, the sexuparae produce the larvae of males and sexual females (gynoparae, only of females; androparae, only of males). Males of some heteroecious species can be produced on the secondary hosts. In a few species remigration takes place in the middle of summer rather than in autumn, resulting in a shortened life cycle (Popova, 1967). Some unusual morphs can be found in a number of aphid taxa, for example, pseudofundatrices in the family Adelgidae, "soldier" larvae incapable of further development and reproduction, in some species of the families Pemphigidae and Hormaphididae, and flying larvae in the genus Periphyllus Hoev (Shaposhnikov, 1986). Due to polymorphism, certain functions are partially distributed between groups of specialized individuals, or morphs. Each morph has its own specific role and appears in specific time during the life cycle. The apterous and alate females are settled and migrating individuals that differ in their morphology, epigenesis, metabolism, behavior, function in the life cycle, and damage to plants.

Damage of aphids can be conditionally subdivided into three categories. The first kind of damage is determined by consumption of considerable amounts of plant sap by aphid colonies, and also the chemical action on the plant. The second kind is related to the possibility of rapid intrapopulation variation. The third kind of damage is related to the ability of aphids to transmit viral diseases of plants. All the three categories of damage are related in one way or another to polymorphism of aphids.

\section{The Gregarious Mode of Life and the Influence on the Host Plant}

Such traits as parthenogenesis, viviparity, polyvoltinism, and formation of "telescoping generations" (with embryos developing inside the larva before it is born) facilitate mass reproduction and aggregation of aphids on host plants. Such aggregation is especially frequently observed in spring and early summer, when plants are more favorable for aphid feeding.

Different authors interpret the phenomenon of aphid aggregation in different ways (Way \& Banks, 1967; Way \& Cammell, 1970; Bonner \& Ford, 1972; Kidd, 1976; Loxdal et al., 1993, etc.). Since aphids are adapted to feeding on assimilates contained in plant sap, they are attracted to the plant's growth zones where they aggregate and reproduce in great numbers, mostly due to rapid development and high fecundity of apterous parthenogenetic females (Sloggett \& Weisser, 2004). There is an interesting hypothesis according to which the first step in the evolution of aptery was related to the possible fecundity gains in the brachypterous forms due to autolysis of the wing muscles. The species producing only alate morphs (the family Drepanosiphidae) and occurring on arboreal hosts have a lower fecundity as compared to the species which also have apterous morphs (Dixon, 1985).

According to our data, the realized fecundity in the bird cherry-oat aphid Rhopalosiphum padi varied between the morphs. During feeding on bird cherry, the mean fecundity was 49-187 larvae in the fundatrices; 39-103 larvae in the apterous fundatrigenous females; $15-55$ larvae in the emigrants. During feeding on favorable secondary hosts, the fecundity was 30-93 larvae in the apterous viviparae and 15-52 larvae in the alate viviparae. Thus, apterous morphs had higher fecundity than alate ones, both on the primary and the secondary host (Vereschagina, 2007). 
The colonies always include more apterous viviparae than alate ones, except for the periods of spring emigration from the primary to the secondary host, return migration in autumn, and the flight peaks in summer.

Due to their colonial mode of life, aphids can "precondition" their trophic substrate for intake by injecting large quantities of salivary gland secretion, and sometimes even gut content, containing digestive enzymes and a powerful set of glycolytic and antioxidant enzymes (Auclair, 1963; Vereschagina, 1982; Vereschagina \& Gandrabur, 1988; Urbanska et al., 1998, 2004; Miles, 1999; Lukasik et al., 2004). As the result of such preconditioning of plant sap, the colonial larvae of Megoura viciae developed faster and more uniformly than isolated ones (Bonner \& Ford, 1972). Two species of cereal aphids, Rh. padi and Rh. maidis, revealed lower mortality rates in case of gregarious, rather than solitary distribution on different genotypes of corn (Vereschagina, 2001). A positive correlation was observed between the colony size in two biotypes of Diuraphis noxia and the success of its reproduction and offspring development on three cultivars of Triticum aestivum (Michaud et al., 2006). In general, the trophic conditions for aphids were shown to be more favorable within the colony than in the case of solitary feeding, as long as the density remained below a certain limit (Way \& Cammell, 1970). The specific microclimate in the colonies may be also important for aphid development.

An increase of the colony size and density beyond a certain limit leads to the local deficiency of food and triggers the intraspecific mechanism of abundance regulation, namely migration of apterous females and formation of alate individuals (Way \& Banks, 1967; An et al., 2012). The load on the host plant is thus reduced to the optimum level.

According to other authors (Kidd, 1976; Loxdale et al., 1993; Ban et al., 2008), aggregation of the larvae and adults of the lime aphid Eucallipterus tiliae is determined by attractiveness of the aphids themselves, rather than by certain properties of the feeding sites. In their opinion, the "group effect" reflects the contact communication of aphids via tactile stimuli perceived by the receptors on their legs, antennae, and bodies. When produced by insects of other species or even by plant fibers, such mechanical stimuli cause a "pseudo-crowding" effect (Lees, 1967). Our experiments confirmed that the "group effect" was mediated by trichoid sensilla located on the legs of aphids. When feeding on the VIR-44 corn variety, the colonial apterous viviparae of Rh. padi with amputated tibiae produced on average $0.3 \%$ of alate offspring in 10 days, as compared to $44 \%$ in aphids with intact tibiae. The ability of contact communication allows the aphids to employ the "dropping" escape response when disturbed by entomophages. In some solitary aphid species the leading role in communication may belong to visual perception (Bonnemaison, 1967; Lees, 1966). However, these behavioral traits do not contradict the role of attractiveness of the plant growth zones, but demonstrate one more positive aspect of the colonial mode of life in aphids.

Thus, the reasons for aggregation of aphids are parthenogenesis, high rates of development, attractiveness of certain feeding sites (the plant growth zones), and the presence of an aggregation attractant; the consequences of aggregation are better trophic conditions, high abundance, timely dispersal, and defense against aphidophages by means of contact communication.

In turn, such a general influence of aphids on the plant induces a variety of defensive and pathological responses involving transport and transformations of primary and secondary metabolites. At low abundance, some species of aphids can even stimulate growth and photosynthesis in their host plants, due to general metabolic enhancement as a manifestation of the initial immune response. In particular, a colony of Brevicorinae brassicae feeding on the mustard plant induced a 70-80-fold increase of sucrose inflow to the feeding site (Way \& Cammell, 1970). According to the data of Ehrhardt (1968), a phloem sap feeding aphid can imbibe the amount of liquid equal to $130 \%$ of its body mass. Considering that one plant can be inhabited by 1000 and more aphids, the loss of sap due to their feeding may be as great as $0.5 \mathrm{ml}$ per hour.

Consumption of plant sap by aphids is accompanied by release of great amounts of excrements (honeydew). The amount and composition of honeydew, as well as of food, vary depending on the aphid species, the host plant, and the external conditions and comprises from 2.0 to $133.0 \%$ of the insect's body mass (Auclair, 1963). Since aphid excrements are rich in sugars, they are colonized by abundant epiphytic microflora (soot-dew, etc.) which reduces the photosynthetic abilities of the host plant by blocking part of the light, causes premature aging of the leaves, and hinders their transpiration and respiration.

Damage by aphids decreases the total solids content as well as the sugar, protein, and vitamin $\mathrm{C}$ content in the leaves of many cultivars. The damaged plants show defects of growth and fruit development and often produce seeds of poor quality (Goszczynski \& Cichocka, 1998).

The agents affecting the trophic substrate are mostly carried by the salivary gland secretions which contain digestive hydrolases and various compounds toxic to plants (Miles, 1999). The interaction of the salivary components of aphids with the defensive secondary metabolites of plants was best studied by the example of cereal aphids. The group of secondary metabolites responsible for aphid resistance in wheat includes hydroxamic acids, 
with DIMBOA (2.4-dihydroxy-7-methoxy-1.4-benzoxazine-3-one) as the main component. As the oral stylets of the aphid damage the plant tissues and reach the phloem, the damaged cell walls and cytoplasmic vacuoles release $\beta$-glucosidase which splits phenolic and flavonoid glucosides to aglucons. Aglucons, in particular DIMBOA, are more toxic to plants and phytophages than their $\beta$-glucoside forms. Synthesis of phenolic compounds in the plant tissue is limited, whereas in the intact cells these compounds are protected from enzymatic oxidation by their isolated position and the presence of antioxidants. However, depletion of the antioxidant reserves in the damaged cells may lead to necrosis (El Naghy \& Shaw, 1966; Miles, 1998). The aphid saliva was found to contain $\beta$-glucosidase, which seems strange since aglucons produced by this enzyme are toxic to aphids; apparently these insects possess a certain mechanism of aglucon detoxification. In addition, it is known that polyphenol oxidase and peroxidase present in the aphid saliva and gut content can rapidly detoxify a great number of phenolic compounds contained in plant sap (Peng \& Miles, 1988; Miles, 1999; Urbanska et al., 2004).

Besides secondary metabolites, the defensive mechanisms of plants may be associated with the structure and function of the sieve tube elements of the phloem. Mature sieve tubes contain great quantities of P-proteins, which seal the pores of the sieve plates in case of damage or at the onset of winter. In case of prolonged damaging influence, the plates of young sieve tube elements are sealed with callose, an easily hydrolysable $1,3-\beta$-glucopolysaccharide (Medvedev, 2004). Callose is highly hygroscopic and protects the cells from drying. In young cells it also serves as a source of carbohydrates since such cells do not possess amyloplasts. Large accumulations of callose have been found in the phloem cells damaged by aphids and around their stylets. Deposits of P-proteins and callose in the pores of the sieve plates block the flow of phloem sap into the aphid's food canal, forcing the insect to change the feeding place. However, aphids may possess some mechanism preventing the formation of seals of P-proteins and callose, since they do not always leave the blocked site. At any rate, during mass feeding on the phloem, when sieve tube sealing appears more probable, the crowded aphids showed a higher level of intestinal proteolytic activity as compared to the solitary females. The sheath of saliva surrounding the aphid stylets protects the plant from mechanical damage and may thus prevent the release of $\beta$-glucosidase and other defensive compounds (Evert et al., 1968; Vereschagina, 2012).

Drying, necroses, and many kinds of deformities of plants caused by aphids impair their trophic conditions. However, some kinds of the plants' response to damage facilitate the development of aphids. For example, gall formation protects aphids from adverse external conditions and creates a favorable feeding zone for them, "prolonging" the plant growth phase. Galls are formed as the result of hypertrophic and hyperplastic development of plant tissue in response to prolonged action of aphids. At the same time, the plant benefits from the feeding of aphids being restricted to the gall zone (Miles, 1999). The gall can be considered as an active biochemical filter that modifies the sap according to the aphids' requirements. It should be noted that modifications occur both in primary and in secondary metabolites. The main components of the aphid saliva participating in gall formation may be $\beta$-indoleacetic acid and amino acids. It is assumed that $\beta$-indoleacetic acid is supplied to the salivary glands via the intestine or is synthesized by oxidative deamination of tryptophan by the saliva oxidases (Miles, 1972). The greatest number of gall-forming species (37) were found in the subfamily Pemphiginae. The representatives of the families Aphididae, Hormaphididae, Drepanosiphidae, and some species of Pemphiginae produce false galls in the form of rolled, bent, and otherwise deformed leaves (Chakrabarti, 2004).

Thus, the plant's response to aphids affecting its metabolism by extraintestinal chemical influence, mechanical damage, and sap consumption has a complex biochemical nature and manifests itself in disruption of many physiological processes. The compounds injected by aphids into the plant tissues usually produce local effects (drying, necrosis, deformities); however, if transported by the vessels, these compounds or products of their metabolism can disrupt the functions of individual organs or the whole plant.

The physiological and biochemical adaptations of different aphid morphs to feeding on primary and secondary hosts are poorly studied. Still, some detoxifying, antioxidant and extracellular enzymes in the intestine of $R h$. padi were shown to have a very low activity in fundatrices, a higher activity in the fundatrigenous generation, and the maximum activity in all the morphs during spring emigration (Lukasik et al., 2004). Fundatrices of Rh. padi died when placed on aging bird cherry leaves although the oviparae could successfully feed on them (Leather \& Dixon, 1981). We also demonstrated an increase in the proteolytic activity in the intestines of the apterous viviparae of $R h$. padi and Rh. maidis feeding on aphid-resistant corn cultivars (Vereschagina \& Gandrabur, 1988).

It may be assumed that responses of different aphid morphs to the composition of plant sap and its changes during the plant ontogenesis may vary depending on the biological specificity of these morphs. 
These and other intricate relations between the aphids and their host plants, allowing the two groups to coexist in nature, were established in the process of evolution. Cultural plants, produced by artificial selection, can change these relations and the ability of aphids to inflict damage.

The physiologically active secondary metabolites of plants, and also insecticides and bacterial toxins are the most widespread and typical inductors of microevolutionary processes in the populations of aphids and other phytophages.

\section{Intrapopulation Variability in Aphids and Their Damage}

The conditions of most modern agrobiocenoses are conducive to faster development of adaptations in insect populations. These processes lead to loss of sensitivity of phytophages to the regularly used chemical agents and the cultivars employing certain resistance mechanisms. Adaptations are known to appear at the greatest rate in the most variable and ecologically flexible insect species.

Aphids provide a perfect object for studying microevolution in insects. Intrapopulation variability in aphids may sometimes lead to the appearance of morphs with different trophic, temperature, and other preferences, and change their status as pests. The second category of damage to plants inflicted by aphids is related to this feature. The intrapopulation changes in the aphid population structure result from preservation and propagation of new morphs, enriching the gene pool. A special role in this process is played by the behavioral and developmental traits of apterous and alate morphs.

The range of phenetic diversity of aphids is enlarged due to polymorphism which is typical of this group. The ontogenetic morphs vary in their time of appearance and sensitivity to trophic and living conditions; therefore they are affected by different selective factors of the environment. There is a mass of evidence concerning the differences in development and behavior of the alate and apterous morphs, in particular their ability to produce males and amphigonic females, demographic parameters, interactions with the host plant, ability to produce alate viviparae in small and large colonies, morphology, and color. Such features as the rapid growth of aphid colonies, the ability of emigrants to settle on differently suitable plants, and the restricted ability of the first apterous generations of the emigrants' progeny to change the host plant when necessary, are all conducive to microevolutionary processes. The alate and apterous morphs also differ in the composition of honeydew, mycetocyte symbionts (Campbell \& Dreyer, 1985), and activity of digestive hydrolases (Vereschagina \& Gandrabur, 1988). These and other parameters are the sources of variation and the basis for selection, both within the clones and among them (Shaposhnikov, 1981). Aphids are characterized by holocentric chromosomes and the thelytokous mode of reproduction, determining a higher level of intraspecific variation and rapid fixation of the accumulated changes (Blackman, 1981).

Different karyotypes of Rh. maidis are known to damage different host plants (Brown \& Blackman, 1988); different forms resistant to insecticides and host plant toxins are also known in Myzus persicae, Sitobion avenae, Acyrthosiphom pisum (Sandström, 1995; Figueroa et al., 2004; Eleftherianos et al., 2004), and many other species. Some authors have considered the probable increase of intrapopulation changes and range expansion of aggressive aphid forms in connection with global warming.

A demand has recently arisen for control of appearance and expansion of especially harmful forms of aphids. For this purpose, changes in the genetic structure of aphid populations are studied using molecular markers and the possibility of genetic mapping is discussed (Llewellin et al., 2003).

Thus, during the life cycle of aphids, the clones best adapted to particular living and feeding conditions undergo selection based on the biotic parameters of the ontogenetic morphs comprising them. In view of this, the abundance of alate migrants is especially important for dispersal of adapted clones.

\section{Alate Morphs in Aphids and Their Role in Interactions With Plants and Other Groups of Organisms}

\subsection{Specific Traits of Damage of Alate Aphid Morphs}

The third category of damage caused to plants by aphids depends not only on their abundance but also on the specific traits of formation and behavior of alate morphs capable of migrating to short and long distances. Alate migrants and viviparae quickly colonize the adjacent territories and can also be carried far away by wind, providing links between the populations in different geographic zones. Alate aphids spread the genotypes resistant to cultivars and insecticides onto new territories (Loxdale et al., 1993), which may result in sudden pest outbreaks. Due to parthenogenesis, a single migrating aphid can potentially found a new population in a previously uninhabited region, or change the clonal composition of the existing local population. If males and sexual females are apterous, the composition of trophic forms can vary even between the fields positioned nor very far apart; this was demonstrated by the example of Acyrthosiphon pisum clones (Sandström, 1995). 
Aphids hold the first place among insects in their ability to transmit viral diseases. Of them, 300 species are presently known to transmit about 200 species of viruses (Dyakonov, 2000). Damage of aphids as virus vectors is manifested even at low abundance, since one alate individual flying from plant to plant can infest many of them. The activity of virus transmission and aphid dispersal is closely connected with the formation of alate morphs and the factors regulating it.

\subsection{Rhythmicity of Wing Induction in Aphids}

The rhythmicity of wing induction in aphids is an ambiguous phenomenon. On the one hand, it has an endogenous nature and does not depend on the density, since alate morphs appear in certain periods of the year. The endogenous factors are the holocyclic or anholocyclic life cycle and the epigenetic factors determining the development of a population. In anholocyclic populations the appearance of first flying adults is mostly determined by the quality of the host plant and the crowding of the colony. Emigrants and remigrants appear in the ontogenesis of heteroecious holocyclic populations according to the innate program of host change (Glinwood \& Petterson, 2000). The so-called fundatrix factor determines the obligatory time gap since the beginning of production of larvae by the fundatrix after which alate gynoparae can start to appear (Lees, 1966). Both alate and apterous viviparae also seem to possess endogenous rhythms of production of offspring belonging to particular morphs. In our long-term research, most clones $(96.9 \%)$ of $R h$. padi emigrants transferred from bird cherry to wheat shoots of the Leningradka variety produced no more than $10 \%$ of alate offspring or no alate individuals at all. It follows from these data that the first summer generations of Rh. padi developing on secondary hosts (the descendants of the emigrants) are usually apterous (Vereschagina, 2008). Therefore, the main spring vectors of viral diseases are alate emigrants which leave the bird cherry in great numbers and visit a wide range of plants in search of suitable hosts.

The first larvae produced by alate viviparae are also always apterous. This was demonstrated by us in two species of cereal aphids: Rh. padi and Rh. maidis (Vereschagina \& Shaposhnikov, 1997). Subsequently the fraction of alate adults in the offspring of alate viviparae increases but their quantity and behavior depend on a number of factors. First, even under the same trophic conditions alate individuals start to appear in the offspring of different clones at different times since the onset of reproduction; second, their number varies without any definite correlation with abundance or colony density, apparently as the result of combination of exogenous and endogenous rhythms; third, alate adults may be not only migratory but also settled (Vereschagina \& Vereschagin, 2013). The offspring of apterous viviparae always includes alate individuals, their number and behavior being similar to the previous variant.

\subsection{Factors Controlling Polymorphism in Virginoparae}

\subsubsection{Crowding}

The principal factor inducing development of the alates in the summer aphid generations is crowding, or the "group effect" (Sutherland, 1969; Vereschagina \& Gandrabur, 1988; An et al., 2012). The group effect modifies the epigenesis of aphids by an endocrine mechanism. In the opinion of most researchers, formation of alate morphs in aphids is controlled by the endocrine system of the maternal generation. A decrease in the activity of corpus allatum reduces secretion of juvenile hormone, thus facilitating wing development (Hardie, 1981).

The embryos remain in the neutral state until they reach a certain stage. The phase of development sensitive to the group effect is species-specific and may be either pre- or postnatal (Ankersmit \& Dijkman, 1983). The crowding effect may sometimes be produced by keeping the aphids together for only several minutes, though usually it takes several hours to develop. Both the age and the density of individuals are significant (Bonnemaison, 1967). At the same time, contrary to what was observed by some authors (Delisle et al., 1983) working with other aphid species, we did not reveal any correlation between the age of apterous viviparae of $R h$. padi and Rh. maidis and the fraction of alate individuals in their offspring (Vereschagina \& Gandrabur, 1988).

The development of alate or apterous viviparae or sexuparae is not solely controlled by the crowding effect. According to some authors, the less important factors are the photoperiod, the host plant, and the temperature (An et al., 2012). A shorter photoperiod has little effect on wing induction in the summer viviparae of both holocyclic and anholocyclic clones, but it is very important for production of autumn remigrants in the period when both the photoperiod and the temperature change (Bonnemaison, 1967; Tsitsipis \& Mittler, 1977). It has been suggested that the effect of environmental factors may be greater at a certain colony density, which was demonstrated by the example of Schizaphis graminum (An et al., 2012). 


\subsubsection{The Host Plant}

There is no consensus as to the role of the trophic factor in wing induction in aphids. Some authors believe that the high percentage of alate adults in aphid colonies does not depend on the biochemical changes induced by their feeding and salivary secretion (Forrest, 1974). By contrast, other authors have shown that the host plant may be the prevalent factor of wing dimorphism in various aphid species, due to its attractiveness, trophic value, and the presence of substances impairing feeding and affecting embryonic development (Harrewijn, 1978). Experiments with artificial substrates revealed a correlation between the number of alate aphids and concentration of amino acids and sucrose in the diet (Mittler \& Kleinjan, 1970). Most studies confirm the influence of the host plant on wing induction in aphids. It is known that apterous females of Sitobion avenae produce fewer alate offspring on winter wheat in the flowering phase when the trophic conditions are favorable, than during the less favorable tillering or ripening phases (Ankersmit \& Dijkman, 1983). Our research showed that feeding on the resistant corn variety A-619 differently increased the number of alate individuals in the offspring of corn and bird cherry-oat aphids (Vereschagina \& Gandrabur, 1988). The number of alate individuals may reflect different trophic specialization of conspecific clones. For example, noticeable changes in the alate morph production were observed when clones of Acyrthosiphum pisum adapted to feeding on pea, clover, or alfalfa were transferred onto other species of host plants (Sandström, 1995). We also demonstrated the effect of the winter wheat cultivar on abundance and composition of offspring in different clones of apterous viviparae of Rh. padi. In the latter case, the number of alate adults and nymphs in the summer offspring of apterous viviparae varied by several times depending on the diet optimality.

Application of fertilizers changes the trophic conditions of the plants and, correspondingly, affects the phloem sap composition, growth rate, and other physiological parameters. Application of plant growth bioregulators together with fertilizers enhances these changes, which are bound to affect the development of aphids. Nitrogen fertilizers particularly affect the quality of plants and the abundance of aphids and entomophages. Although the response of aphids to fertilizers is species-specific, enhancement of plant growth usually increases the size and density of aphid colonies (Dudnik, 1985; Garratt et al., 2010; Stafford et al., 2012) and, correspondingly, the fraction of alate morphs in the offspring and the migration intensity.

\subsubsection{Consort Associations}

Wing induction and migration in aphids are also affected by such factors as infestation with viruses and parasites and the presence of ants and other predators (Bonnemaison, 1967; Gutierres et al., 1980; Gildow, 1983; Sudd, 1987).

For example, predators visiting aphid colonies disturb the aphids, which may increase the number of alate females in their offspring, but lowering the colony density may have the opposite effect. It is known that attendance by various species of ants (Formicinae) reduces the number of alate morphs in the aphid population (Sudd, 1987). However, the various kinds of relations between ants and aphids, ranging from mutualism to predation, can modify this effect since, on the one hand, ants reduce the number of other disturbing visitors, and on the other hand, they can also consume and disturb aphids (Novgorodova, 2005; Stadler \& Dixon, 2005). When attacked by predators, aphids synthesize and release the alarm pheromone (E)- $\beta$-farnesene. This volatile compound can act as a communication agent causing the "pseudo-crowding" effect and increasing the number of alate morphs in the offspring of crowded aphids but not of solitary ones (Kunert et al., 2005). Aphids infected with viruses become more sensitive to the alarm pheromone and leave the plant quickly (Ban et al., 2008). As distinct from the effects of parasites and predators, infestation with entomopathogenic fungi and viruses was shown to induce alate morph formation in Acyrthosiphon pisum and Dysaphis plantaginea independently of physical contacts between aphids; this effect was not related to that of pseudo-crowding (Ryabov et al., 2009; Hatano et al., 2012).

The various factors and their most probable effects on aphid polymorphism are shown in Figure 1. The system shown in the figure optimizes the levels of abundance and dispersal of aphids in relation to their mode of life, epigenesis, and behavior as well as the abiotic, biotic, and anthropogenic environmental factors. 


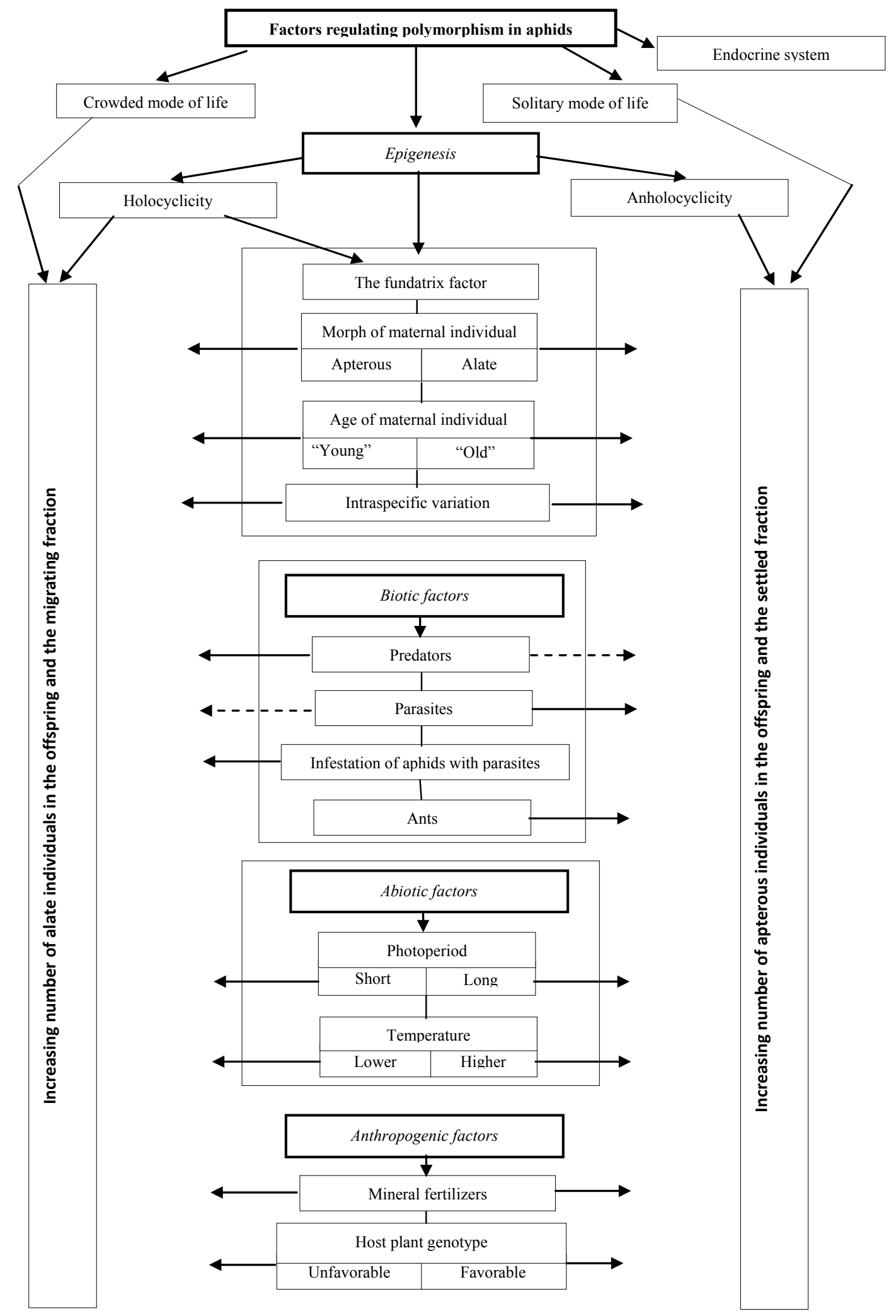

Figure 1. Factors regulating polymorphism in aphids

Note:

less probable action of the factor 


\subsection{Specific Traits of the Aphid Flight and Transmission of Viral Diseases}

In order to monitor the dispersal and distribution of aphids over cultivars, one has to know not only the factors determining wing induction but also the specific traits of the aphid flight. The behavior of aphids in flight is primarily determined by biological motivations that underlie the behavioral responses of phytophages (Vilkova, 1979).

Aphids have two types of flight: the migration (long-distance) flight typical of spring emigrants, autumn remigrants, and some alate individuals in the summer population, and the trivial (short-distance) flight typical of alate viviparae. The migration flight is obligatory and takes place even when the host plant is favorable, while the trivial flight largely depends on external factors. The specificity of the two types of flight was covered in detail in the reviews (Müller, 1962; Vereschagina \& Vereschagin, 2013, etc.). The composition of emigrants and alate viviparae by their tendency to long- or short-distance flights or settled existence may vary within the clone depending on the host plant (Vereschagina \& Vereschagin, 2013). The flight motivation is related to the reproductive states of alate aphids which vary even among individuals in conspecific clones. Aphids having large gonads show a tendency to trivial flights, whereas those with small gonads but considerable fat reserves usually fly to long distances (Walters \& Dixon, 1983). Some alate individuals may be sedentary while some apterous ones may be migratory. The apterous adults and larvae migrate to short distances. According to our data, the migrating fraction of the summer generations of Rh. padi includes $60 \%$ or more of alate morphs, $19 \%$ of apterous adults, and up to $5 \%$ of larvae. Nymphs rarely participate in migration. In the beet root aphid Pemphigus fuscicornis and some other species the function of dispersal is performed by the I instar larvae referred to as "crawlers." In A. fuscicornis such larvae have a low sailing capacity and can be carried by wind to small distances only; they disperse actively via soil fissures and infest the roots of beet and some wild representatives of Chenopodiaceae (Gorbatyuk, 1969).

The migration flight is obligatory and takes place even when the host plant is favorable. Aphids in general are poor fliers but they can remain in the air for up to $14 \mathrm{~h}$ and can be carried to hundreds of kilometers by wind as part of the anemoplankton. The flight velocity of aphids varies from 0.8 to $3.3 \mathrm{~km} / \mathrm{h}$ depending on the wind. Aphids need light to fly and take off at an illumination of $1000 \mathrm{~lx}$. Bright sunlight (10700 lx) decreases the flight activity of aphids but the illumination thresholds are species-specific. The most active flight is usually observed in the morning and $1-2 \mathrm{~h}$ before sunset but some species also fly in the night. The mean lower temperature threshold of the aphid flight is $+13-15^{\circ} \mathrm{C}$, and the upper one, $+31^{\circ} \mathrm{C}$ (Robert, 1987). The flight peaks of summer viviparae depend on the air temperature and the species' abundance during the most favorable phases of the host plants. For example, the bird cherry-oat and corn aphids have two flight peaks during the season: on corn and sorghum the first peak is observed near the end of stage VIII of the plant organogenesis, whereas the second peak starts with stage X and lasts until stage XII. Some aphids have a unimodal flight (Guidelines, 1983).

The dynamics of aphid flight is monitored by the network of suction traps established in Europe, which helps to protect plants from damage. Each trap provides a representative sample of aphids within the radius of $20-50 \mathrm{~km}$ (Dixon, 1987). The modern global climatic changes affect the phenology of aphids and correlation of their development with that of their host plants. The unequal changes in the rates of development of plants and aphids increase the probability of dissociation of their relations and changes in their dynamics and dispersal (Harrington et al., 1999). As shown by the cited authors, the dispersal of migrants allows them to "scan" large territories. The flight is followed by the search for host plants which is accomplished, similar to other insects, by distant, contact, and gustatory orientation (Vilkova, 1979). Distant orientation of emigrants and viviparae is limited by their weak sensitivity to low concentrations of volatile compounds (Anderson \& Bromley, 1987; Webster, 2012), therefore during the host search aphids often land on unfavorable plants, mostly on wild herbaceous ones. Although aphids leave such plants quickly, after a few shallow punctures (contact and gustatory orientation), noncirculative phytopathogenic viruses get attached to the tips of their stylets and can be transferred by the insect onto other plants. Circulative viruses can be transmitted only several days after feeding on the infested plant, because they have to multiply first and reach the insect's digestive system (Zykin, 1970; Keldysh \& Pomazkov, 2003).

The intensity of aphid flight is particularly significant for transmission of viral diseases; for example, the potato virus $\mathrm{Y}$ can be transmitted by many aphid species which do not colonize the potato plants themselves, such as Anoecia corni, Aphis rumicis, Phorodon humuli, Rh. padi, and others (Heimbach et al., 1998). The barley yellow dwarf virus is known to be widely distributed on representatives of the family Poaceae. It is therefore not surprising that the virus itself and its vectors, aphids of the genus Rhopalosiphum, have a common center of origin located in North America (Halbert \& Voegtlin, 1998). This historically established trophic association allows these aphids to transmit the virus to cultured grasses during their long- and short-distance migrations.

According to our observations, of special interest are the aphid species transmitting the non-persistent plum pox virus distributed in Moldova, where plum trees occupy the second largest fraction of orchard territories, yielding 
only to apple trees. This virus is also present in Russia: in Krasnodar and Stavropol Territories, Rostov, Volgograd, Voronezh, and other provinces (Kuleshova \& Rynza, 2010). The virus vectors developing on plum trees in Moldova are Hyalopterus pruni subsp. pruni, Brachycaudus cardui, B. helichrysi, and Myzus persicae. In Russia, this list is supplemented with Aphis craccivora, M. varians, and Ph. humili (Kuleshova \& Rynza, 2010).

In spring, after the imaginal molt on plum trees, the aphids lose the virus and migrate onto herbaceous plants; however, in autumn the plum trees get infected by the gynoparae and males remigrating from one tree to another (Verderevskaja et al., 1983). Transmission of the virus from infected plants to healthy ones can be explained by the fact that the gynoparae and males, like the corresponding morphs of $R h$. padi, still consume some sap from the primary host plants (Walters et al., 1984). So far, the only known ways to decrease infestation in the plum pox virus foci are the application of aphicides after harvesting in order to kill the alate remigrants, and also removal of weeds on which the vector aphid species may develop.

\section{Can Aphids be Beneficial?}

However, most species of aphids do not form outbreaks and do not transmit viral diseases of plants, therefore they do not act as agricultural pests at low abundance (Miles, 1999). The other side of the biology of aphids is their positive role in the functioning of biogeocenoses. Many forest aphids are consumed by the same entomophages which destroy aphid pests. The aphid honeydew serves as food for ants and some nectar-feeding insects, including the adults of parasitic and predatory entomophages, and also bees and other pollinators. In forests, aphids act as a factor stabilizing the abundance of insects. The sugars of the honeydew get into the soil, increasing the abundance of nitrogen-fixing bacteria and improving the soil composition (Vereschagin et al., 1985).

\section{Conclusion}

The relation between polymorphism in aphids and their damage is characterized. The key factors controlling polymorphism in aphids are classified for the first time and a diagram showing their action is proposed.

The damage of aphids is shown to be related to the ability of apterous viviparae to rapidly increase their abundance. Due to high fecundity and development rate, feeding on phloem sap in the zones of high content of assimilates, and the action of aggregation attractant, apterous viviparae can form large aggregations. On the one hand, group action of aphids on the host plant optimizes their feeding and provides the means of contact communication, which are particularly important in case of danger. On the other hand, crowded aphids reduce the amount of nutrients in the plant, contaminate it with excrements, and cause various deformations and metabolic disturbances which may eventually kill the plant.

The damage of aphids is also determined by their wide ecological plasticity and the formation and dispersal of aggressive intrapopulation forms. Besides, it is related to the ability of most alate morphs: emigrants, alate viviparae, gynoparae, and males, to transmit viral diseases of plants and to disperse onto new territories, spreading the harmful intrapopulation forms.

The alate morphs appear at certain stages of the life cycle in accordance with endogenous rhythms. Wing induction in summer aphid populations is primarily affected by the colony density and deterioration of the trophic conditions, and also by the presence of entomophages, parasites, and pathogens.

Thus, the importance of alate morph formation as a factor of aphid damage has been demonstrated; this factor should be taken into account during development of new strategies of plant protection, including selection of resistant cultivars. The positive role of aphids in ecosystems is one of the aspects of the biocenotic approach to plant protection.

\section{References}

An, C., Fei, X., Chen, W., \& Zhao, Z. (2012). The integrative effects of population density, photoperiod, temperature and host plant on the induction of alate aphids in Schizaphis graminum. Archives of insect biochemistry and physiology, 79(4-5), 198-206. http://dx.doi.org/10.1002/arch.21005

Anderson, M., \& Bromley, A. K. (1987). Sensory system. In A. K. Minks, \& P. Harrewijn (Eds.), Aphids: Their Biology, Natural Enemies and Control (pp. 153-162). Amsterdam: Elsevier.

Ankersmit, G. W., \& Dijkman, H. (1983). Alatae production in the cereal aphid Sitobion avenae. Netherlands Journal of Plant Pathology, 89, 105-112. http://dx.doi.org/10.1007/BF01976349

Auclair, J. L. (1963). Aphid feeding and nutrition. Annual Review of Entomology, 8, 439-490. http://dx.doi.org/10.1146/annurev.en.08.010163.002255 
Ban, L., Ahmed, E., Ninkovic, V., Delp, G., \& Glinwood, R. (2008). Infection with an insect virus affects olfactory behavior and interactions with host plant and natural enemies in an aphid. Entomologia experimentalis et applicata, 127(2), 108-117. http://dx.doi.org/10.1111/eea.2008.127.issue-2

Blackman, R. L. (1981). Aphid genetics and host plant resistance. International organization for Biological Control of Noxious Animals and Weeds. West Palearctic Regional Section Bulletin, IV, 13-19.

Bonnemaison, L. (1967). L'effect de group chez les aphids. Colloques internationaux du centre National de la Recherche Scientifique, 173, 213-236.

Bonner, A. B., \& Ford, J. B. (1972). Some effects of crowding on the biology of Megoura viciae. Annals of Applied Biology, 71(2), 91-98. http://dx.doi.org/10.1111/j.1744-7348.1972.tb02943.x

Brown, P. A., \& Blackman, R. L. (1988). Karyotype variation in the corn leaf aphid Rhopalosiphum maidis species complex (Hemiptera: Aphididae) in relation to host plant and morphology. Bulletin of Entomological Research, 78, 351-363. http://dx.doi.org/10.1017/S0007485300013110

Campbell, B. C., \& Dreyer, D. L. (1985). Host-plant resistance of sorghum: differential hydrolysis of sorghum pectic substances by polysaccharases of greenbug biotipes (Schizaphis graminum: Homoptera, Aphididae). Archives of Insect Biochemistry and Physiology, 2, 213-215.

Chakrabarti, S. (2001). Host plant association and utilization of gall forming aphids (Homoptera: Aphididae) in western and northwest Himalayas. In J. C. Simon, C. A. Dedryver, C. Rispe, \& M. Hulle (Eds). Aphids in a New Millennium: Proceedings VI International Symposium on Aphids (pp. 125-130). Rennes 3-7 Sept., France, 2001. Paris: INRA.

Delisle, J., Clauter, C., \& McNeil, J. N. (1983). Precocene II-induced alate production in isolated and crowded alate and apterous virginoparae of the aphid Macrosiphum euphorbiae. Journal of Insect Physiology, 29, 477-484. http://dx.doi.org/10.1016/0022-1910(83)90078-1

Dixon, A. F. G. (1977). Aphid ecology: life cycles, polymorphism and population dynamics. Annual Review of Ecology and Systematics, 8, 329-353. http://dx.doi.org/10.1146/annurev.es.08.110177.001553

Dixon, A. F. G. (1985). Structure of Aphid Populations. Annual Review of Entomology, 30, 155-174. http://dx.doi.org/10.1146/annurev.en.30.010185.001103

Dixon, A. F. G. (1987). Cereal Aphids as an Applied Problem. Agricultural Zoology Reviews, 2(November), 1-57.

Dudnik, G. F. (1985). Population dynamics and damage of the grain aphid in Vinnitsa Province. Biological and chemical plant protection from pests, diseases and weeds in the Ukrainian SSR. Kiev, 150-156.

Dyakonov, K. P. (2000). Insects as a factor of dispersal of phytopathogenic viruses in the Russian Far East. A.I. Kurentsov Memorial Lectures. Vladivostok: Biology and Soil Institute, XI, 15-26.

Ehrhardt, P. (1968). Einfluss von Ernährungsfaktoren auf die Entwicklung von Säfte saugenden Insekten unter besonderer Berücksiehtigung von Symbionten. Zeitschrift für Parasitenkunde, 31(1), 38-36. http://dx.doi.org/10.1007/BF00716427

El Naghy, M. A., \& Shaw, M. (1966). Correlation between Resistance to Stem Rust and the Concentration of a Glucoside in Wheat. Nature, 210(5034), 417-418. http://dx.doi.org/10.1038/210417a0

Eleftherianos, I., Foster, S., Goodson, S., Williamson, M., \& Denholm, I. (2004). Toxicological and molecular characterization of pyrethroid knockdown resistance ( $k d r)$ in the peach-potato aphid Myzus persicae (Sulzer). J.-Ch. Simon, Ch.-A Dedryver, C. Rispe, M. Hulle (Eds). Aphids in a New Millennium: Proceedings VI International Symposium on Aphids (pp. 213-218). Rennes 3-7 Sept., France, 2001. Paris: INRA.

Evert, R. F., Eschrich, W., Meddler, J. T., \& Alfieri, F. J. (1968). Observations on penetration of linden branches by stylets of the aphid Longistigma caryae. American Journal of Botany, 55(7), 860-874. http://dx.doi.org/10.2307/2440974

Figueroa, C. C., Simon, J. C., Dedryver, C. A., \& Niemeyer, H. M. (2004). Genetic variability of the recently introduced Sitobion avenae in Chile. In J. C. Simon, C. A. Dedryver, C. Rispe, \& M. Hulle (Eds), Aphids in a New Millennium: Proceedings VI International Symposium on Aphids (pp. 219-225). Rennes 3-7 Sept., France, 2001. Paris: INRA.

Forrest, J. M. S. (1974). The effect of crowding on morph determination of the aphid Dysaphis devecta. Journal of Entomology, A48(2), 171-175. 
Garratt, M. P. D., Wright, D. J., \& Leather, S. R. (2010). The effects of organic and conventional fertilizers on cereal aphids and their natural enemies. Agricultural and Forest Entomology, 12(3), http://dx.doi.org/307-318.10.1111/j.1461-9563.2010.00480.x

Gildow, F. E. (1983). Influence of barley yellow dwarf virus-infected oats and barley on morphology of aphid vectors. Phytopathology, 73(73), 1196-1199. http://dx.doi.org/10.1094/Phyto-73-1196.

Gliwood, R. T., \& Petterson, J. (2000). Host choice and host leaving in Rhopalosiphum padi (Hemiptera: Aphididae) emigrants and repellency of aphid colonies on the winter host. Bulletin of Entomological Research, 90, 57-61. http://dx.doi.org/10.1017/S0007485300000717

Gorbatyuk, N. M. (1969). The beet root aphid (Pemphigus fuscicornis Koch) in Moldavia. Candidate's dissertation in biology. Kishinev: Institute for Zoology. 20 pp.

Goszczynski, W., \& Cichocka, E. (1998). Effects of aphids on their host plants. J. M. N. Nafria, A.F.G. Dixon (Eds), Aphids in Natural and Managed Ecosystems: Proceedings V International Symposium on Aphids (pp. 197-203). 15-19 Sept., Leon, 1997. Leon: Universidad de Leon.

Gutierres, A. P., Summers, C. G., \& Baumgaertner, J. (1980). The phenology and distribution of aphids in California on alfalfa as modified by ladybird beetle predation (Coleoptera: Coccinellidae). Canadian Entomologist, 112, 489-495. http://dx.doi.org/10.4039/Ent112489-5

Halbert, S. E., \& Voegtlin, D. J. (1998). Evidence for the North American origin of Rhopalosiphum and Barley Yellow Dwarf Virus. In J. M. N. Nafria, \& A.F.G. Dixon (Eds), Aphids in Natural and Managed Ecosystems: Proceedings V International Symposium on Aphids (pp. 351-356). 15-19 Sept., Leon, 1997. Leon: Universidad de Leon.

Hardie, J. (1981). Juvenile hormone and photoperiodically controlled polymorphism in Aphis fabae: postnatal effects on presumptive gynoparae. Journal of Insect Physiology, 27(5), 347-355. http://dx.doi.org/10. 1016/0022-1910(81)90059-7

Harrewijn, P. (1978). The role of Plant Substances in Polymorphism of the Aphid Myzus persicae. Entomologia experimentalis et applicata, 24(3), 198-214.

Harrington, R., Woiwod, I., \& Sparks I. (1999). Climate change and trophic interactions. Tree, 14(4), 146-150. http://dx.doi.org/10.1016/S0169-5347(99)01604-3.

Hatano, E., Baverstock, J., Kunert, G., Pell, J., K., \& Weisser, W. W. (2012). Entomopathogenic fungi stimulate transgenerational wing induction in pea aphids, Acyrthosiphon pisum (Hemiptera: Aphididae). Ecological Entomology, 37, 75-82. http://dx.doi.org/10.1111/j.1365-2311.2011.01336.x

Heimbach, U., Thieme, T., Weidemann, H. L., \& Thieme, R. (1998). Transmission of potato virus Y by aphid species which do not colonize potatoes. In J. M. N. Nafria, \& A. F. G. Dixon (Eds), Aphids in Natural and Managed Ecosystems: Proceedings V International Symposium on Aphids (pp. 555-559). 15-19 Sept., Leon, 1997. Leon: Universidad de Leon.

Keldysh, M. A., Pomazkov, Y. I. (2003). Viruses, viroids and mycoplasmata of plants: A brief study manual. Moscow: Peoples' Friendship University of Russia. 157 pp.

Kidd, N. A. C. (1976). Aggregation in the lime aphid (Eucallipterous tiliae L.) 2. Social aggregation. Oecologia, 25(2), 175-185. http://dx.doi.org/10.1007/BF00368852

Kuleshova, Yu. G., \& Rynza, E. T. (2010). The plum pox virus in the Russian Federation. Zashchita i karantin rastenii. Retrieved October 10, 2010, from http://rostov.vniikr.ru/articles/4231/

Kunert, G., Otto, S., Röse, Ursula S. R., Gershenzon, J., Weisser, \& Wolfgang W. (2005). Alarm pheromone mediates production of winged dispersial morphs in aphids. Ecology letters, 8, 596-603. http://dx.doi.org/10.1111/j.1461-0248.2005.00754.x

Leather, S. R., \& Dixon, A. F. G. (1981). Growth, survival and reproduction of the bird-cherry oat aphid, Rhopalosiphum padi, on its primary host. Annals of Applied Biology, 99, 115-118. http://dx.doi.org/10.1111/j.1744-7348.1981.tb05136.x

Lees, A. D. (1966). The control of polymorphism in Aphids. Advances in Insect Physiology, 3, 207-277. http://dx.doi.org/10.1016/S0065-2806(08)60188-5 
Lees, A. D. (1967). The production of the apterous and alate forms in the aphid Megoura viciae Buckton, with special reference to the role of crowding. Journal of Insect Physiology, 13, 289-318. http://dx.doi.org/10.1016/0022-1910(67)90155-2

Llewellin, K. S., Loxdale, H. D., Harrington, R., Brookes, C. P., Clark, S. J., \& Sunnucks, P. (2003). Migration and genetic structure of the grain aphid (Sitobion avenae) in Britain related climate and clonal fluctuation as revealed using microsatellites. Molecular Ecology, 12, 21-34. http://dx.doi.org/10.1046/j.136 5-294X.2003.01703.x

Loxdale, H. D., Hardie, J., Halbert, S., Foottit, R., \& Kidd, N. A. C. (1993). The relative importance of short- and long-range movement of flying aphids. Biological Reviews, 68(2), 291-311. http://dx.doi.org/10.1111/j.1469-185X.1993.tb00998.x

Lukasik, I., Leszczynski, B., \& Dixon, A.F.G. (2004). Changes in bird cherry-oat aphid metabolism while occurring on primary host. In J.-Ch. Simon, Ch.-A Dedryver, C. Rispe, M. Hulle (Eds.), Aphids in a New Millennium: Proceedings VI International Symposium on Aphids (pp. 463-469). Rennes 3-7 Sept., France, 2001. Paris: INRA.

Medvedev, S. S. (2004). Plant physiology. Saint-Petersburg State Univ. 335 pp.

Michaud, J. P., Jyoti, J. L., \& Qureshi, J. A. (2006). Positive correlation of fitness with group size in two biotypes of Russian Wheat Aphid (Homoptera: Aphididae). Journal of Economic Entomology, 99(4), 1214-1224. http://dx.doi.org/10.1603/0022-0493-99.4.1214

Miles, P. W. (1972). The saliva of Hemiptera. Advances of Insect Physiology, 9, 183-255. http://dx.doi.org/10.1016/s0065-2806(08)60277-5

Miles, P. W. (1998). Aphid salivary functions: the physiology of deception. In J. M. N. Nafria, A. F. G. Dixon (Eds.), Aphids in Natural and Managed Ecosystems: Proceedings VInternational Symposium on Aphids (pp. 255-263). 15-19 Sept., Leon, 1997. Leon: Universidad de Leon.

Miles, P.W. (1999). Aphid saliva. Biological Reviews, 74(1), 41-85. http://dx.doi.org/10.1017/S00063231980 05271

Mittler, T. E., \& Kleinjan, J. E. (1970). Effect of artificial diet composition on wing-production by the aphid Myzus persicae. Journal of Insect Physiology, 16(5), 833-850.

Müller, H. J. (1962). Moderne Vorstellungen über Biologie und Ökologie des Blattlausflüges und seine Bedeutung für die Virusausbreitung. Zeitschrift für Pflanzenkrankheiten und Pflanzenschutz, 69(7), 385-392. http://dx.doi.org/10.1016/0022-1910(70)90217-9

Novgorodova, T. A. (2005). Specific traits of mutualistic relations with aphids in two ant species of the genus Lasius (Formicinae). Uspekhi sovremennoi biologii, 125(2), 199-205.

Peng, Z., \& Miles, P. W. (1988). Studies on the salivary physiology of plant bugs: Function of the catechol oxidase of the rose aphid. Journal of Insect Physiology, 11, 1027-1033. http://dx.doi.org/10.1016/0022-1910(88) 90202-8

Popova, A. A. (1967). Adaptations of aphids to feeding on their host plants. Leningrad: Nauka. 292 pp.

Powel G., \& Hardie J. (2001). The chemical ecology of aphid host alternation: how do return migrants find the primary host plant? Applied Entomology and Zoology, 36, 259-267. http://dx.doi.org/10.1303/aez.2001.259

Robert, Y. (1987). Aphids and their environment. Dispersion and migration. In A. K. Minks, P. Harrewijn (Eds.), Aphids: Their Biology, Natural Enemies and Control (pp. 299-313). Amsterdam: Elsevier, A.

Ryabov, E. V., Keane, G., Naish, N., Evered, C., \& Winstanley, D. (2009). Densovirus induces winged morphs in asexual clones of the rosy apple aphid, Dysaphis plantaginea. Proceedings of the National Academy of Sciences of the United States of America, 106, 8465-8470. http://dx.doi.org/10.1073/pnas.0901389106

Sandström, J. (1995). Temporal changes in host adaptation in the pea aphid, Acyrthosiphon pisum. In J. Sandström (Ed.), Host adaptation in the pea aphid. Temporal changes and nutrition. Dissertation. Department of Entomology Swedish University of Agricultural Sciences: Uppsala, IV, 1-17.

Shaposhnikov, G. C. (1981). Populations and species in aphids and need for a Universal species concept. Special Publication Research Branch Agriculture. Canada. P. 61.

Shaposhnikov, G. C. (1986). New species of the genus Dysaphis Börrn. (Homoptera, Aphidinea) and peculiarities of the taxonomic work on aphids. Entomologicheskoe obozrenie, 36(1), 535-550. 
Sloggett, J. J., \& Weisser, W. W. (2004). A general mechanism for predator and parasitoid - induced dispersal in the pea aphid Acyrthosiphon pisum. In J.-Ch. Simon, Ch.-A Dedryver, C. Rispe, \& M. Hulle (Eds). Aphids in a New Millennium. Proceedings VI International Symposium on Aphids (pp. 79-85). Rennes 3-7 Sept., France, 2001. Paris: INRA.

Sobetsky, L. A. (1967). Some specific traits of trophic physiology of aphids. Candidate's dissertation in biology. Kishinev: Institute for Zoology. $20 \mathrm{pp}$.

Stadler, B., Dixon, \& A. F. G. (2005). Ecology and Evolution of Aphid-Ant Interactions. Annual Review of Ecology, Evolution and Systematics, 36, 345-372. http://dx.doi.org/10.1146/annurev.ecolsys.36.091704.1 75531

Stafford, D. B., Tariq, M., Wright, D. J., Rossiter, J. T., Kazana, E., Leather, S. R., Ali, M., \& Staley J. T. (2012) Opposing effects of organic and conventional fertilizers on the performance of a generalist and a specialist aphid species. Agricultural and Forest Entomology, 14(3), 270-275. http://dx.doi.org/10.1111/j.1461-9563. 2011.00565.x

Sudd, J. H. (1987). Ant aphid mutualism. A. K. Minks, \& P. Harrewijn (EDds.), Aphids: Their Biology, Natural Enemies and Control (Vol. A, pp. 355-365). Amsterdam: Elsevier.

Sutherland, O. R. W. (1969). The role of crowding in the production on wing forms by two strains of the pea aphid Acyrthosiphon pisum. Journal of Insect Physiology, 15, 1385-1410. http://dx.doi.org/10.1016/00221910(69)90199-1

Tsitsipis, J. A., \& Mittler, T. E. (1977). Influence of daylength on the production of parthenogenetic and sexual females of Aphis fabae at 17.5 . Entomologia experimentalis et applicata, 21(2), 163-173. http://dx.doi.org/10.1007/BF00287091

Urbanska, A., Leszcsynski, B, Matok, H., \& Dixon, A. F. G. (2004). Hydrolysis of plant glycosides by cereal aphids. In J.-Ch. Simon, Ch.-A Dedryver, C. Rispe, \& M. Hulle (Eds.), Aphids in a New Millennium. Proceedings VI International Symposium on Aphids (pp. 521-527). Rennes 3-7 Sept., France, 2001. Paris: INRA.

Urbanska, A., Leszczynski, B., Laskowska, I., \& Matok, H. (1998). Enzymatic defense of grain aphid against plant phenolics. In J. M. N. Nafria, \& A. F. G. Dixon (Eds.), Aphids in Natural and Managed Ecosystems: Proceedings V International Symposium on Aphids (pp. 119-124). 15-19 Sept., Leon, 1997. Leon: Universidad de Leon.

Verderevskaja, T. D, Vereschjagin, B. V., Andreev, A. V., \& Polynkovsky, A. I. (1983). The epidemiology of plum pox virus in Moldavia. Acta Horticulturae (Canada), 130, 317.

Vereschagin, B. V., Andreev, A. V., \& Vereshchagina, A. B. (1985). The Aphids of Moldavia. Kishinev: Shtiintsa.

Vereschagina, A. B. (1982). The physiological peculiarities of trophic specialization of aphids as related to plant resistance. Candidate's dissertation in biology. Leningrad: All Union Institute for Plant Protection.

Vereschagina, A. B. (2001). The effect of the host plant genotype and crowding on development and mortality rates of cereal aphids (Homoptera: Aphididae). Trudy Rossiiskogo entomologicheskogo obshchestva, 72, 83-88.

Vereschagina, A. B. (2007). Adaptive variation of Aphids as the Basis for Criteria of Phenetic Monitoring of Their Populations. In V. A. Pavljushin (Ed.), International Organization for Biological Control of Noxious Animals and Plants (pp. 56-60). East Palearctic Regions Section. Newsletter. Saint-Petersburg: All Russian Institute for Plant Protection.

Vereschagina, A. B. (2008). Ecological mechanisms of phenotypic and genotypic variation of the aphid population structure. Modern problems of plant immunity to harmful organisms: Collected works of the 2nd All-Russian Conference (pp. 197-200). September 29 - October 2, 2008. Saint-Petersburg.

Vereschagina, A. B. (2012). Development of clones of the bird cherry-oat aphid Rhopalosiphum padi (L.) (Homoptera: Aphididae) as related to the resistance mechanisms of soft spring wheat of Delfi 400 cultivar. Proc. of XIV Congress of Russian Entomological Society, August 27 - September 1, 2012. Saint-Petersburg.

Vereschagina, A. B., \& Shaposhnikov, G. C. (1998). Influence of crowding and host-plant on development of winged and apterous aphids. In J. M. N. Nafria, \& A. F. G. Dixon (Eds.), Aphids in Natural and Managed Ecosystems: Proceedings V International Symposium on Aphids (pp. 642-645). 15-19 Sept., Leon, 1997. Leon: Universidad de Leon. 
Vereschagina, A. B., \& Vereschagin, B. V. (2013). Classification of host plants of aphids (Homoptera, Aphidoidea) as related to their selection and use by aphids under the recent conditions of biogeocenosis transformation. Entomologicheskoe obozrenie, XLII(2), 265-281.

Vereshchagina, A. B., \& Gandrabur, S. I. (1988). Behavioral responses of cereal aphids feeding on corn plants with different degrees of resistance. Ekologiya, 2, 35-39.

Vilkova, N. A. (1983). Guidelines for estimation of pest resistance of cereal cultivars (1983). N.A. Vilkova (Ed.), Leningrad: All-Union Institute for Plant Protection. 46 pp.

Vilkova, N. A. (1979). Plant immunity to pests and its relation to the trophic specialization of phytophagous insects. N.A. Kholodkovsky Memorial Lectures, 11 April 1978. Saint-Petersburg: Zoological Institute, 31, 68-103.

Walters, K. F. A., \& Dixon, A. F. G. (1983) Migratory urge and reproductive investment in aphids: Variation within clones. Oecologia, 58, 70-75. http://dx.doi.org/10.1007/BF00384544

Walters, K. F. A., Dixon, A. F. G., \& Eagles, G. (1984). Non-feeding by adult gynoparae of Rhopalosiphum padi and its bearing on the limiting resource in the production of sexual females on host-alternating aphids. Entomologia Experimentalis et Applicata, 36, 9-12. http://dx.doi.org/10.1111/j.1570-7458.1984.tb03398.x

Way, M. J., \& Banks, C. J. (1967). Intraspecific mechanisms in relation to the natural regulation of numbers of Aphis fabae Scop. Annals of Applied Biology, 59(2), 189-205. http://dx.doi.org/10.1111/j.1744-73 48.1967.tb04428.x

Way, M. J., \& Cammell, M. (1970). Aggregation behavior in relation to food utilization by aphids. In A. Watson (Ed.), Animal Populations in Relation to their Food resources (pp. 229-246). Oxford-Edinburgh.

Webster, B. (2012). The role of olfaction in aphid host location. Physiological Entomology, 37, 10-18. http://dx.doi.org/10.1111/j.1365-3032.2011.00791.x

Zykin, A. G. (1970). Aphids as vectors of potato viruses. Leningrad: Kolos.

\section{Copyrights}

Copyright for this article is retained by the author(s), with first publication rights granted to the journal.

This is an open-access article distributed under the terms and conditions of the Creative Commons Attribution license (http://creativecommons.org/licenses/by/3.0/). 